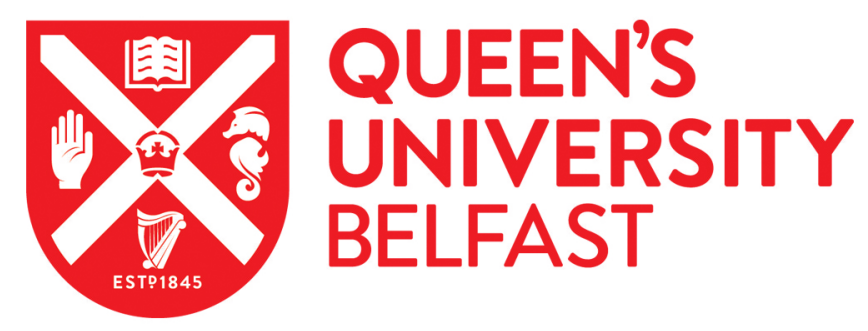

\title{
Written corrective feedback practices of an experienced ESL primary teacher: An ecological perspective
}

Chong, S. W. (2020). Written corrective feedback practices of an experienced ESL primary teacher: An ecological perspective. TESOL Journal, [e00509]. https://doi.org/10.1002/tesj.509

\section{Published in:}

TESOL Journal

\section{Document Version:}

Peer reviewed version

Queen's University Belfast - Research Portal:

Link to publication record in Queen's University Belfast Research Portal

Publisher rights

Copyright 2020 Wiley. This work is made available online in accordance with the publisher's policies. Please refer to any applicable terms of use of the publisher.

\section{General rights}

Copyright for the publications made accessible via the Queen's University Belfast Research Portal is retained by the author(s) and / or other copyright owners and it is a condition of accessing these publications that users recognise and abide by the legal requirements associated with these rights.

Take down policy

The Research Portal is Queen's institutional repository that provides access to Queen's research output. Every effort has been made to ensure that content in the Research Portal does not infringe any person's rights, or applicable UK laws. If you discover content in the Research Portal that you believe breaches copyright or violates any law, please contact openaccess@qub.ac.uk. 
This is an accepted version of the paper which will appear in TESOL Journal (Wiley):

Chong, S. W. (2020). Written corrective feedback practices of an experienced ESL primary teacher: An ecological perspective. TESOL Journal, $x x(\mathrm{x}), \mathrm{xx}-\mathrm{xx}$.

\title{
Written Corrective Feedback Practices of an Experienced ESL Primary Teacher: An Ecological Perspective
}

\begin{abstract}
Research into written corrective feedback (WCF) in English-as-an-Second-Language (ESL) contexts has been burgeoning in the past decades, focusing mostly on its effectiveness and students' preferences. Nevertheless, studies focusing on school settings and teachers' perspective are scant. In particular, very few studies venture to examine the interrelationship between individual teachers and contexts, and how such interplay affects teachers' WCF strategies. Adopting an ecological perspective to language learning and teaching, this phenomenological study sheds light on a situated experience of a senior ESL teacher in a primary school in Hong Kong who implemented customized WCF strategies in a Grade 4 writing classroom. Findings suggest that teacher agency and autonomy played a pivotal role in enabling the teacher to perceive and act on the affordances provided by unfavourable, neutral/unrelated, and favourable circumstances. Implications for ESL teacher preparation and development programs are offered.
\end{abstract}

Keywords: Written corrective feedback; ESL; primary education; ecological perspective

\section{Introduction}

In the past 20 years, two streams of written corrective feedback (WCF) ${ }^{1}$ research have been conducted to inform ESL/EFL teachers' feedback practices: quasiexperimental studies (e.g., Shintani, Ellis, \& Suzuki, 2014) and naturalistic classroombased studies (e.g., Ene \& Kosobucki, 2016). Findings from the two lines of research indicate that WCF is effective in developing ESL/EFL learners' linguistic accuracy and that WCF is positively valued by learners (Chong, 2018; 2019). Nevertheless, the majority of the WCF studies focus on ESL/EFL college and university students in the U.S., New Zealand, China, and Taiwan. Very few studies have examined the effectiveness and practices of WCF in school contexts, especially in ESL/EFL primary school contexts. Studies examining WCF practices for young ESL/EFL learners are warranted because effective intervention in the form of feedback should begin in an earlier stage of learning (Lee, 2008). Moreover, naturalistic classroom-based studies focusing on the perception of ESL primary teachers will provide valuable insights into the appropriate and effective WCF strategies for young ESL learners, which remains an under-explored area in feedback literature. Responding to a recent call by Storch (2018) to conduct WCF studies which take into consideration the interplay between

\footnotetext{
${ }^{1}$ Written corrective feedback (WCF) refers to error correction in written form by teachers. In the literature, different WCF strategies have been documented, including focused/unfocused, direct/indirect, metalinguistic explanations. For a review of the different types of WCF, refer to Chong (2019).
} 
individuals and contexts, an ecological perspective on language teaching was adopted to examine how a senior English teacher's WCF practice in a primary school in Hong Kong is shaped by the interrelationship between personal and contextual factors (Han, 2019). Specifically, this brief report addresses this research question: What are the personal and contextual factors that, and how do these factors, shape the teacher's WCF practice?

\section{Methodology}

The current study was conducted in a Grade 4 writing classroom in a coeducational primary school in Hong Kong. Purposeful sampling was adopted when selecting the teacher participant. Gwen was invited to participate in the study because she has 15 years of teaching experience and is an experienced English teacher. Additionally, Gwen oversees the school's curriculum development and she expressed enthusiasm in implementing effective WCF practices through her informal conversations with the researcher. According to Gwen, the English writing ability of class she taught is low to average. With her teaching experience, seniority in the school, and her passion for refining her feedback practice, data collected from Gwen would shed important light on the research question.

Informed by an ecological perspective on language teaching, the focus of this study is on how (1) the individual perceives possible action given the resources of the context (affordances) and (2) her motivation to act on such perception (Han, 2019). This investigation is an in-depth phenomenological study to shed light on the situated nature of WCF practices of an ESL primary school teacher and the interplay of factors which shape the feedback practices. The aim of this phenomenological study is not to present generalizable findings but to inquire into an individual's lived experience with the interpretative lenses of the participant and the researcher through interviews (Webb \& Welsh, 2019). Data from three rounds of individual semi-structured teacher interviews were used to probe into Gwen's experience and perception of WCF. The three interviews, which were conducted in the participant's first language, Cantonese, as per the interviewee's request, include one pre-study interview and two post-marking interviews; these interviews were fully translated and transcribed by a research assistant. The transcripts were cross-checked by the researcher and were analyzed both inductively and deductively following an iterative coding process.

\section{Findings and discussion}

Regarding Gwen's WCF practices, she implemented indirect WCF (the use of error codes) and focused WCF (the correction of selected type(s) of language errors) ${ }^{2}$. Two contextual factors provide the impetus for Gwen to implement indirect WCF: a student literacy development program and teacher appraisal.

In one of the interviews, Gwen became convinced that indirect WCF would work on primary ESL students because of a program her school joined which aimed to develop Grades 1-3 students' reading and writing literacies. In the program, there was

\footnotetext{
${ }^{2}$ Analysis of Gwen's WCF practices is not detailed in this article because the focus of this research brief is on Gwen's perception and experience of WCF.
} 
an activity designed to encourage students to check the spelling of some words without telling them the correct answers. Gwen believed that such an implicit approach could be transferred to how she gave feedback to students to raise their grammatical awareness. Another contextual factor which provided the extrinsic motivation for Gwen to implement indirect WCF was teacher appraisal. According to Gwen, the English Panel Chairperson required all English teachers to use codes when giving feedback to students, and she even posted a marking codes sheet in classrooms so that students could check the meanings of the codes when they do corrections. Despite the requirements of the English Panel Chairperson to employ indirect WCF, Gwen did not fully implement it, as shown from her feedback given to her students. Gwen, instead, adopted indirect WCF only on a number of grammatical items which she thought her students could manage. In Gwen's opinion, if indirect WCF was not introduced gradually and selectively, it would be detrimental to the writing and linguistic development of her students, especially those who are less proficient in English.

From an ecological perspective, it is shown that two contextual factors are available which offer the affordances, or opportunities, for Gwen to implement indirect WCF. Nevertheless, from what is described above, it is Gwen, as an autonomous agent, who acted on such opportunities to adopt a customized approach of indirect WCF as one of her feedback strategies. Regarding the affordances of the student literacy development program, Gwen was inspired by how the self-editing strategy she learned in the program could be transferred to giving written feedback to students. In terms of teacher appraisal, it definitely provided the extrinsic motivation for her to implement indirect WCF; however, she did not blindly follow the instructions of the English Panel Chairperson and used all the codes on the marking codes sheet. Instead, taking into consideration her students' readiness and English proficiency, Gwen adapted the practice to make it progressive and selective.

Similar to Gwen's implementation of indirect WCF, her adoption of focused WCF was influenced by a number of contextual and personal factors.

Contextually, Gwen's selection of feedback focuses was influenced by the curriculum guide written by the Education Bureau of the Hong Kong SAR government. For instance, Gwen often commented on students' use of adjectives in compositions because the use of adjectives is underscored in the official curriculum document. Students' need was another external force which influenced Gwen's selection of feedback focus. One of the feedback focuses of Gwen was students' use of connectives. Her decision to focus on connectives when giving feedback was informed by the fact that her students were weak in elaborating their ideas in writing, and Gwen believed that students' use of connectives would enable them to include more ideas in their compositions. Another grammar item Gwen decided to focus on in her feedback was verb tenses. This decision was informed by the writing curriculum of her school. In the first semester, two of the three writing units were recounts. To Gwen, students' ability to use the past tense accurately is especially important given the genre in focus.

An additional contextual factor, parents' concerns, proved to be a constraint to Gwen's adoption of a focused approach to giving feedback. Gwen admitted that some parents were skeptical regarding the effectiveness of giving feedback selectively. Despite the oppositions from parents, it is Gwen's personal belief and experience that WCF is more effective to young ESL learners when given in a focused manner. In 
addition, Gwen believed that focused WCF is more effective than unfocused WCF because teachers need less time to finish giving feedback to students. In other words, when Gwen's feedback belief contradicts with the parents' preference to correct errors comprehensively, Gwen was steadfast in her belief; Gwen was able to convince herself that her belief is grounded on her observation of her students' needs and practical constraints.

Informed by Han's (2019) ecological view on language teaching, the ways Gwen navigated through a plethora of contextual variables would be highlighted. Similar to her decision to adopt a gradual and selective approach to implementing indirect WCF, Gwen's decision to give feedback in a focused manner was largely influenced by her agency as a teacher, which gives her insights into perceiving the affordances offered in the environment. For instance, she managed to align her feedback practice with the official curriculum requirements, the school's teaching scheme, and her students' needs. In other words, she perceived these external factors not as constraints but opportunities for her to implement innovative feedback practices. To Gwen, the implementation of focused WCF did not stem from school requirements, but her perception that it would solve the problems she identified in her school environment. In addition to being perceptive, Gwen's personal belief fueled her motivation to give feedback in a focused manner. She believed that her students, given their general low English writing ability, could benefit more from doing corrections on a small number of carefully chosen grammatical items. It is precisely Gwen's personal belief and perception of opportunities embedded in the environment which provided her the impetus to implement focused WCF, in spite of some parents' disapproval. Different from some secondary English teachers in Hong Kong who succumbed to school administrators to give WCF in a certain way because of accountability (Lee, 2008), Gwen was resolute in her belief that a gradual and focused approach to giving indirect WCF is suitable for her students despite the Panel Chairperson's requirement to fully implement indirect WCF. Such difference may be due to the fact that Gwen is an experienced teacher and she holds a management position at the school which gives her the insights into the needs of her students and the assurance that she has the autonomy to deviate from the required practice of the English Panel Chairperson.

\section{Implications and conclusion}

It is important to examine the interrelationship between personal and contextual factors and how these interactions shape teachers' WCF practices which do not take place in a vacuum (Storch, 2018). Adopting an ecological frame of mind on language teaching, the present phenomenological study underscores how the interchange between an individual and context shape a teacher's feedback practices. The findings of this study, despite lacking generalizability due to the nature of the study, offer an indepth analysis of factors which underpin a situated and personalized feedback model. Moreover, the findings indicate that contextual factors, be them favorable (e.g. Gwen's students' needs), neutral/unrelated (e.g. a literacy development program for primary school students), or unfavorable (e.g. parents' concerns), were present in the context where Gwen teaches. While it is understandable that favorable circumstances facilitate the implementation of new assessment practices, the findings of this study have shown that neutral/unrelated and even unfavorable circumstances could be conducive to the 
enactment of feedback innovations. The key to activating the affordances offered by these less favorable contextual factors lies in teacher autonomy, which is defined by Lin and Reinders (2018) as teachers' attitudes, ability, and behaviors to take ownership of their teaching. Building on the preliminary findings of this study about the focal role played by teacher autonomy in shaping an experienced ESL primary teacher's WCF practices, future WCF studies could adopt a multiple case-study design to compare personal and contextual factors which affect WCF practices of novice and experienced teachers, or more autonomous and less autonomous teachers.

\section{References}

Chong, S. W. (2019). A systematic review of written corrective feedback research in ESL/EFL contexts. Language Education \& Assessment, 2(2), 70-95. doi:10.29140/lea.v2n2.138

Chong, S. W. (2018). A three-stage model for implementing focused written corrective feedback. TESL Canada Journal, 34(2), 71-82. doi:10.18806/tesl.v34i2.1267

Ene, E., \& Kosobucki, V. (2016). Rubrics and corrective feedback in ESL writing: a longitudinal case study of an L2 writer. Assessing Writing, 30, 3-20. doi:10.1016/j.asw.2016.06.003

Han, Y. (2017). Mediating and being mediated: learner beliefs and learner engagement with written corrective feedback. System, 69, 133-142. doi:10.1016/j.system.2017.07.003

Han, Y. (2019). Written corrective feedback from an ecological perspective: The interaction between the context and individual learners. System, 80, 288-303. doi:10.1016/j.system.2018.12.009

Lee, I. (2008). Understanding teachers' written feedback practices in Hong Kong secondary schools. Journal of Second Language Writing, 17, 69-85. doi:10.1016/j.jslw.2007.10.001

Lin, L., \& H. Reinders. (2019). Students' and teachers' readiness for autonomy: beliefs and practices in developing autonomy in the Chinese context. Asia Pacific Education Review, 20(1), 69-89. doi:10.1007/s12564-018-9564-3

Little, D. (1995). Learning as dialogue: the dependence of learner autonomy on teacher autonomy. System, 23(2), 175-181. doi:10.1016/0346-251x(95)000066

Shintani, N., Ellis, R., \& Suzuki, W. (2013). Effects of written feedback and revision on learners' accuracy in using two English grammatical structures. Language Learning, 64(1), 103-131. doi:10.1111/lang.12029 
Sortkær, B. (2019). Feedback for everybody? Exploring the relationship between students' perceptions of feedback and students' socioeconomic status. British Educational Research Journal. Online First. doi:10.1002/berj.3522

Storch, N. (2018). Written corrective feedback from sociocultural theoretical perspectives: a research agenda. Language Teaching 51(2), 262-277. doi:10.1017/s0261444818000034

Webb, A., \& Welsh, A. J. (2019). Phenomenology as a methodology for scholarship of teaching and learning research. Teaching \& Learning Inquiry: The ISSOTL Journal 7(1), 168-181. doi:10.20343/teachlearninqu.7.1.11 